\title{
Geoelectric investigation to delineate groundwater potential and recharge zones in Suki river basin, north Maharashtra
}

\author{
Gautam Gupta $^{1, *}$, S N Patil ${ }^{2}$, S T Padmane ${ }^{2,3}$, Vinit C Erram ${ }^{1}$ and S H Mahajan ${ }^{1}$ \\ ${ }^{1}$ Indian Institute of Geomagnetism, Kalamboli Highway, Navi Mumbai 410 218, India. \\ ${ }^{2}$ School of Environment and Earth Sciences, North Maharashtra University, Jalgaon 425 001, India. \\ ${ }^{3}$ Groundwater Surveys and Development Agency, Nagpur, Maharashtra 444 602, India. \\ *Corresponding author.e-mail: ggupta@iigs.iigm.res.in
}

Suki river basin of Raver sub-division is located towards the northeastern part of Jalgaon district in Maharashtra State. The existing land use pattern of the region clearly shows that more than $60 \%$ of the area is utilized for agricultural sector. Groundwater is the major source of irrigation and domestic purposes. To assess the overall water resources development of Raver area for better environment in future, investigation was carried out with the help of geophysical indicators. Vertical electrical sounding studies were conducted at 17 stations in the study area using Wenner configuration. The study was aimed at characterizing the aquifer in the area as well as assessing its potential risk to contaminant seepage in terms of protective capacity of the overburden rock materials using Dar- $Z$ arrouk (D-Z) parameters, viz., the transverse resistance $(T)$, longitudinal conductance $(S)$, transverse resistivity $\left(\rho_{t}\right)$ and longitudinal resistivity $\left(\rho_{l}\right)$. These were computed to generate the resistivity regime of freshwater-bearing formations and its movement. The central-western part of the study area reflects very good to good protective capacity rating as can be seen from the high longitudinal conductance values. The low value of the protective capacity in the eastern part is making the aquifer system in the area highly vulnerable to surface contamination. This indicates that the ground water quality may have been deteriorated in the area and borehole water samples should be randomly sampled for contaminant loads based on this analysis.

\section{Introduction}

Water is a prime necessity of life and has been fundamental for the development of civilization from the ancient period. The beginning of our civilization was confined to river basins and early settlements were associated with proximity of surface water such as springs, running streams and rivers. Many civilizations came into existence around perennial water resources. The need to prospect for additional groundwater sources in a typically hard-rock terrain like Raver sub-division in Jalgaon district, Maharashtra, became inevitable in order to to cope with the ever increasing population, basic amenities and rapid development for utilizing the water resources for their increasing needs.

The vertical electrical sounding (VES) technique has been effectively used by many researchers in diverse fields of application including groundwater investigations (Devi et al. 2001; Lenkey et al. 2005; Hamzah et al. 2007; Gupta et al. 2012), groundwater contamination studies (Karlik and Kaya 2001; Park et al. 2007; Frohlich et al. 2008; Kundu and Mandal 2009; Maiti et al. 2013a; Mondal et al.

Keywords. Groundwater; resistivity; Dar-Zarrouk parameters; protective aquifer capacity; Raver; Jalgaon. 
2013), saltwater intrusion problems (Edet and Okereke 2001; Hodlur et al. 2006; Song et al. 2007; Adeoti et al. 2010; Hermans et al. 2012; Maiti et al. 2013b; Gupta et al. 2014), and geothermal explorations (El-Qady et al. 2000; Majumdar et al. 2000; Kumar et al. 2011).

Several researchers have carried out systematic hydrogeological and geophysical studies in the Deccan trap region (Bose and Ramakrishna 1978; Singhal 1997; Pawar et al. 2009; Rai et al. 2011; Ratnakumari et al. 2012; Rai et al. 2013) to delineate aquifers and the occurrence and movement of groundwater in intertrappeans/vesicular and fractured zones within the trap sequence and sedimentary formations below the traps, which are considered to be a potential source of groundwater.

With the available database in the northern part of Deccan Volcanic Province (DVP), Central Groundwater Board (CGWB) (http://cgwb.gov. in/CR/achi_geo_stu.html) has established standardized resistivity ranges for different litho units in respect of water bearing zones in the Deccan basalts. These studies have reported that for weathered/fractured vesicular basalt saturated with water, the resistivity values are of the order of 20-45 $\Omega-\mathrm{m}$. The moderately weathered/fractured basalt/vesicular basalt saturated with water has a resistivity range of 40-70 $\Omega-\mathrm{m}$, whereas, hard, compact and massive basalts have been assigned resistivity values of $>70 \Omega$-m.

The study was aimed at characterizing the aquifers, to delineate the depth of the aquifer and its lateral extent and to estimate the aquifer protective capacity in the area as well as assessing its recharge capability using Dar-Zarrouk (D-Z) parameters in the Raver area of Jalgaon district, Maharashtra (figure 1a).

\section{Physiography and geology of the region}

The Suki river basin is located in the northeastern part of Jalgaon district of Maharashtra State (figure 1a). It is a tributary of the Tapi River and originates in Madhya Pradesh and enters into Maharashtra at north of the village Pal in Raver sub-division and meets river Tapi at village Hatnur. The total area covered under study is about $328 \mathrm{~km}^{2}$. The area is included in Survey of India toposheet nos. $46 \mathrm{O} / 11, \mathrm{O} / 12, \mathrm{O} / 15, \mathrm{O} / 16$ and $55 \mathrm{C} / 4$ and lies between $75^{\circ} 44^{\prime} 00^{\prime \prime}-75^{\circ} 56^{\prime} 02^{\prime \prime}$ east longitude and $21^{\circ} 04^{\prime} 25^{\prime \prime}-21^{\circ} 21^{\prime} 43^{\prime \prime}$ north latitude. The mean sea level (MSL) ranges from 180 to $1074 \mathrm{~m}$. The study area experiences a semi-arid climate. The average annual rainfall of the area is about $742 \mathrm{~mm}$. The maximum temperature ranges from 29 to $48^{\circ} \mathrm{C}$, while the minimum temperature ranges from 12 to $24^{\circ} \mathrm{C}$.
The area includes the undulating piedmont plains along southern fringe of Satpuda hills and the flood plains of Tapi River. The general gradient is southwards. The topography in combination with the nature of soil and sediments is largely responsible for the high surface run-off, poor infiltration and its impact on consequent scarcity of ground/surface water resources. Many streams originate from Satpuda ranges, flow towards south and ultimately discharge into the Tapi River. The dendrites and parallel drainage pattern is clearly seen in the study area. Hatnur Right Bank Canal is also passing from the southern part of the area which helps in replenishment of groundwater (Chavan and Nile 2012). The regional geology (figure 1b) of the region is described by Lamsoge (2009) and is given in table 1.

The entire region is covered by a thin layer of alluvial soil of varying thicknesses. This soil cover is underlain by a composite layer of younger and older alluvium. This layer is further underlain by weathered and highly fractured basalts (Deshpande 1998). The location map and general geology of the study area is shown in figure 1(a and b). Groundwater in Deccan Trap Basalt occurs mostly in the upper weathered and fractured parts down to 20-25 m depth. Potential groundwater zones are encountered at deeper levels in parts of Raver in the form of fractures and in intertrappean zones, which are sedimentary formations deposited during the interval of two consecutive lava flows. Intertrappeans together with the vesicular basalt units form groundwater potential zones between two compact basalt layers (Rai et al. 2011) If the intertrappean bed is clay rich, then it is not a likely source of groundwater. Such beds are termed as bole beds (Ghosh et al. 2006). The upper weathered and fractured parts form phreatic aquifer and groundwater occurs under water table (unconfined) conditions. At deeper levels, the groundwater occurs under semi-confined conditions.

The yield of dug wells, tapping upper phreatic aquifer, ranges between 21 and $337 \mathrm{~m}^{3} /$ day, which have a depth range of $5-15 \mathrm{~m} \mathrm{bgl}$. Bore wells drilled down to $60-150 \mathrm{~m}$ depths, tapping weathered and vesicular basalt are found to yield $1.8-52 \mathrm{~m}^{3}$ /day. On the other hand, groundwater in alluvium occurs under water table, semi-confined and confined conditions (Lamsoge 2009). The average thickness of aquifer ranges from 4 to $9 \mathrm{~m}$. The pre-monsoon static water level ranges from 5 to $11.60 \mathrm{~m}$, while the post-monsoon static water level ranges from 2 to $8.35 \mathrm{~m}$.

Presently, groundwater withdrawal in the study area for irrigation and domestic uses are from dug wells penetrating approximately $5-15 \mathrm{~m}$ depths up to the bottom of weathered/fractured mantle. 

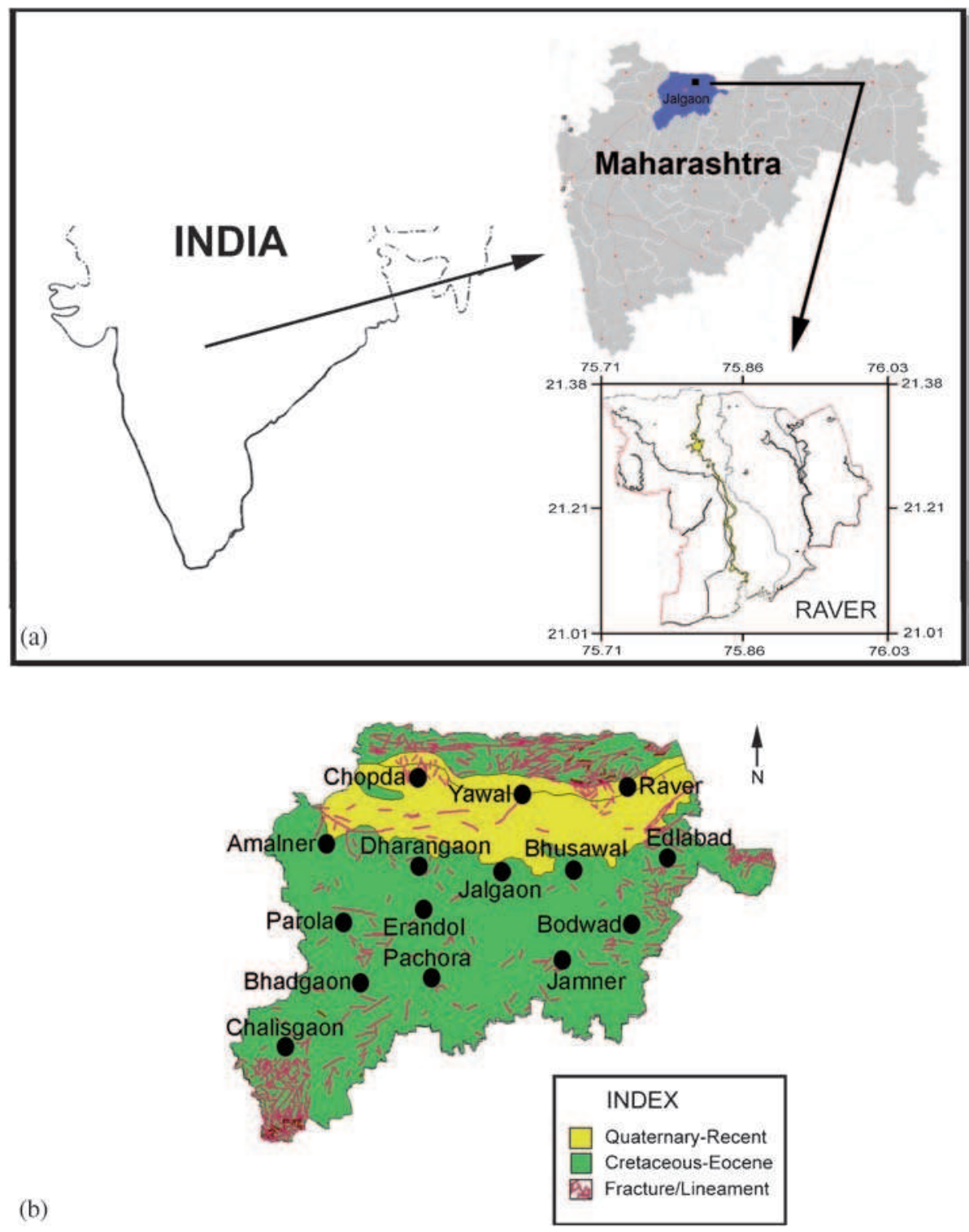

Figure 1. Map depicting (a) the location of the study area in Raver sub-division of north Maharashtra and (b) the general geology of Jalgaon district. Also shown are the lineaments present in the region.

Table 1. Regional geology of the study area.

\begin{tabular}{ll}
\hline Recent & \multicolumn{1}{c}{ Alluvium } \\
\hline $\begin{array}{l}\text { Quaternary to Recent } \\
\text { Upper Cretaceous-Lower Eocene }\end{array}$ & $\begin{array}{l}\text { Bazada (Talus and Scree), younger alluvium and older alluvium } \\
\text { Basalt (Deccan Traps) }\end{array}$ \\
\hline
\end{tabular}

Most of the dug wells go dry during summer season. Thus, availability of water in these dug wells is inadequate to meet the present demand of water supply. The unpredictable fluctuation in rainfall tends to aggravate the problem. Excessive pumping of groundwater resources for cash crop like banana has also caused depletion in water table.

\section{Survey design}

In the DC resistivity method, current is introduced directly into the ground through a pair of current electrodes and the resulting voltage difference is measured between a pair of potential electrodes. This method provides the apparent resistivity distribution against depth. The depth of penetration 
of electrical signal is generally found to be approximately one-third of the distance between the electrode separations (Dahlin 2000; Maiti et al. 2011). This method is carried out to decipher problems of aquifer in hard formation such as the Deccan Trap region.

A total of 17 resistivity soundings were carried out in the study area using Aqua-II plus D.C. resistivity meter manufactured by Minitronics, Pune. The general hydrological conditions were ascertained on the basis of geomorphologic setting and lithological characteristics of different alluvial beds exposed in dug wells. Representative areas of different hydrological environments were then selected for resistivity survey. The Wenner configuration of equally spaced electrode distribution was employed in the present survey. The current electrodes were placed $300 \mathrm{~m}$ apart to obtain information up to a depth of approximately $100 \mathrm{~m}$. The data obtained from the field was processed and modelled using IPI2WIN software, version 3.0.1.a7.01.03 (Bobachev 2003) for interactive semi-automated interpretation. It is observed that most of the sounding curves in the area reflect much variation in the curve type and suggests $4-5$ layered structure in the study area. The layer resistivity, layer thickness, total thickness $(\mathrm{H})$ and the RMS error for all the 17 VES stations are shown in table 2 .

\section{Analysis of VES data}

Maillet (1947) termed the Dar-Zarrouk (D-Z) parameters $(T$, transverse resistance and $S$, longitudinal conductance). $T$ is the resistance normal to the face and $S$ is the conductance parallel to the face for a unit cross-section area, which plays an important role in resistivity soundings. D-Z parameters are sufficient for computing the distribution of surface potential and hence electrical resistivity graphs (Henriet 1976). Later on, many other workers (Niwas and Singhal 1981, 1985; Shahid and Nath 2002; Singh et al. 2004; Khalil 2006; Mondal et al. 2013) studied the significance of D-Z parameters for obtaining hydrological properties of the aquifers.

In the present study, the D-Z parameters (Singh and Singh 1970; Henriet 1976; Salem 1999; Ayolabi et al. 2010) namely longitudinal unit conductance $(S)$, transverse unit resistance $(T)$, transverse resistivity $\left(\rho_{t}\right)$, longitudinal resistivity $\left(\rho_{l}\right)$, coefficient of anisotropy $(\lambda)$ and root mean square resistivity $\left(\rho_{m}\right)$, have been adopted to analyze the data.

Let us consider a prism of unit cross-section which is characterized by its thickness ' $h$ ' and resistivity ' $\rho$ '. Then the resistance $(T)$ perpendicular to

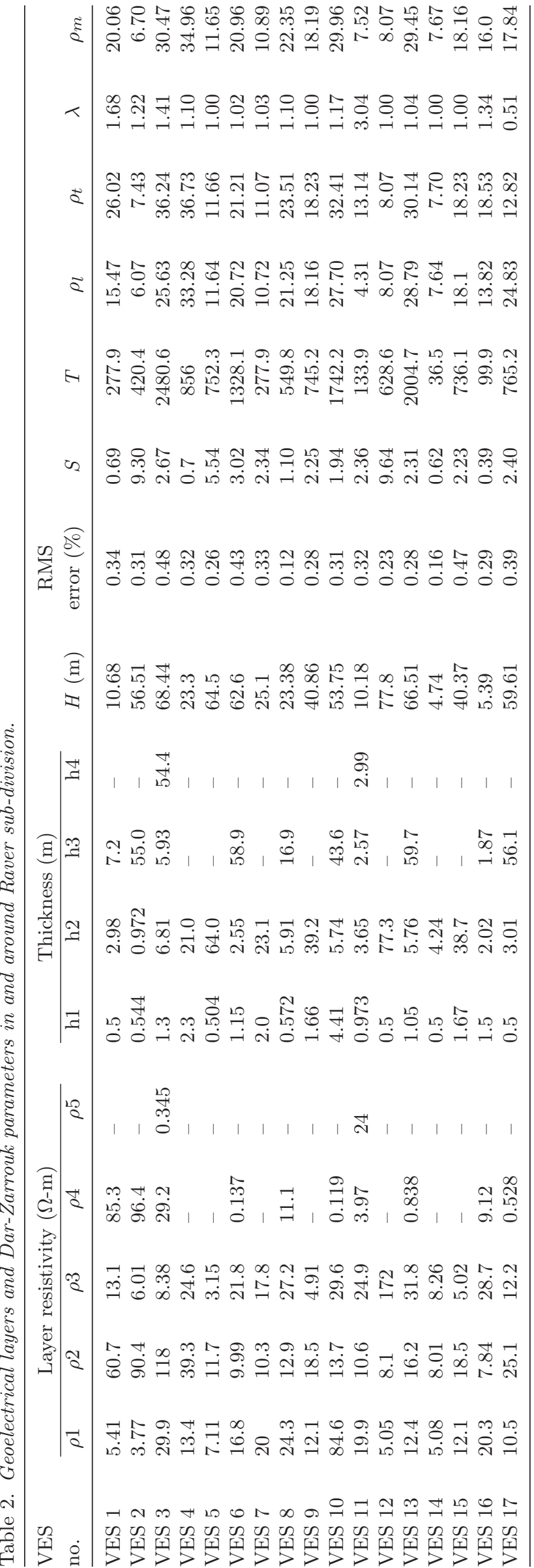


the face of the prism and the conductance $(S)$ parallel to the face of prism (Mondal et al. 2013) can be written as:

$$
T=h \times \rho,
$$

and

$$
S=\frac{h}{\rho} .
$$

It is considered that the prism consists of $n$ geoelectrical layers and is completely characterized by its thickness $h_{1}, h_{2}, \ldots, h_{n}$ and resistivities $\rho_{1}$, $\rho_{2}, \ldots, \rho_{n}$, respectively. Then, the total resistance of the current flowing perpendicular to the layers will be the sum of resistance offered by each layer and can be expressed as follows:

$$
T=h_{1} \rho_{1}+h_{2} \rho_{2}+\cdots+h_{n} \rho_{n},
$$

or

$$
S=\sum_{i=1}^{n} h_{i} * \rho_{i} .
$$

This is 'transverse resistance'.

The transverse resistivity to the current flowing perpendicular to the layers is given by:

$$
\rho_{t}=\frac{T}{H},
$$

where $H=\sum h_{i}$ and $H$ being the depth to the bottommost geoelectric layer.

Similarly, the total conductance of the current flowing parallel to the layers can be expressed as:

$$
S=\frac{h_{1}}{\rho_{1}}+\frac{h_{2}}{\rho_{2}}+\cdots+\frac{h_{n}}{\rho_{n}},
$$

or

$$
S=\sum_{i=1}^{n} \frac{h_{i}}{\rho_{i}} .
$$

This is 'longitudinal conductance'.

The longitudinal resistivity of the current flowing parallel to the layers is given by:

$$
\rho_{l}=\frac{H}{S} \text {. }
$$

The coefficient of pseudo-anisotropy $(\lambda)$ is given by:

$$
\lambda=\sqrt{ }\left(\rho_{t} / \rho_{l}\right) .
$$

The root mean square resistivity, also known as effective resistivity, is given as:

$$
\rho_{m}=\sqrt{ }\left(\rho_{t} * \rho_{l}\right) .
$$

The above parameters were used for delineating the sub-surface freshwater zones in the study region and to determine the aquifer protective capacity.
As mentioned earlier, Henriet (1976) showed that the combination of layer resistivity and thickness in the D-Z parameters $S$ (longitudinal conductance) and $T$ (transverse resistance) may be of direct use in aquifer protection studies and for the evaluation of hydrologic properties of aquifer. The protective capacity is considered to be proportional to the longitudinal unit conductance $(S)$ (Oladapo et al. 2004; Ayolabi 2005; Atakpo and Ayolabi 2008; Atakpo 2013). Thus, the overburden protective capacity was evaluated using the total longitudinal unit conductance $(S)$ values (Henriet 1976; Oladapo et al. 2004; Atakpo and Ayolabi 2008; Atakpo 2013).

\section{Results and discussion}

\subsection{Estimation of Dar-Zarrouk parameters}

As mentioned earlier, a total of 17 VES were carried out using Wenner configuration in the study region (figure 2 ). The data were acquired between the latitudes $21.10^{\circ}-21.30^{\circ}$ and longitudes $75.82^{\circ}-$ $76.06^{\circ}$ in the Raver sub-division of Jalgaon district, northern Maharashtra. In order to characterize the aquifers, to delineate the depth to the aquifer and its lateral extent and to estimate the aquifer protective capacity in the area as well as assessing its recharge capability, contour maps for longitudinal conductance $(S)$, transverse resistance $(T)$, transverse resistivity $\left(\rho_{t}\right)$, longitudinal resistivity $\left(\rho_{l}\right)$, anisotropy $(\lambda)$ and root mean square resistivity $\left(\rho_{m}\right)$ were generated. This will aid in understanding the spatial variation of these parameters to demarcate the fresh water bodies, to envisage effect of saline water ingress, if any, and to delineate the groundwater potential zones. The $\mathrm{D}-\mathrm{Z}$ parameters in the study area are given in table 2 .

\subsubsection{Longitudinal unit conductance}

The longitudinal conductance $(S)$ varies from 0.39 to 9.64 in the study area with a contour interval of 0.5 (figure $3 \mathrm{a}$ ). It can be clearly seen that there is a distinct boundary at the central part of the study area. The eastern part is infested with low $S$ values (0.39-1), encompassing VES stations 1, 4 and 14, whereas the central part is characterized by $S$ values greater than 3 at VES stations 3, 6 and 11 . Very high $S$ values $(>6)$ are observed at VES stations 2, 5 and 12. Elsewhere, the $S$ value is moderate. It can be envisaged that the VES stations with low to moderate $S$ value (0.39-5) represents freshwater region.

The longitudinal conductance $(S)$ gives information about the variation of the highly resistive fresh basement topography as depth to the basement 


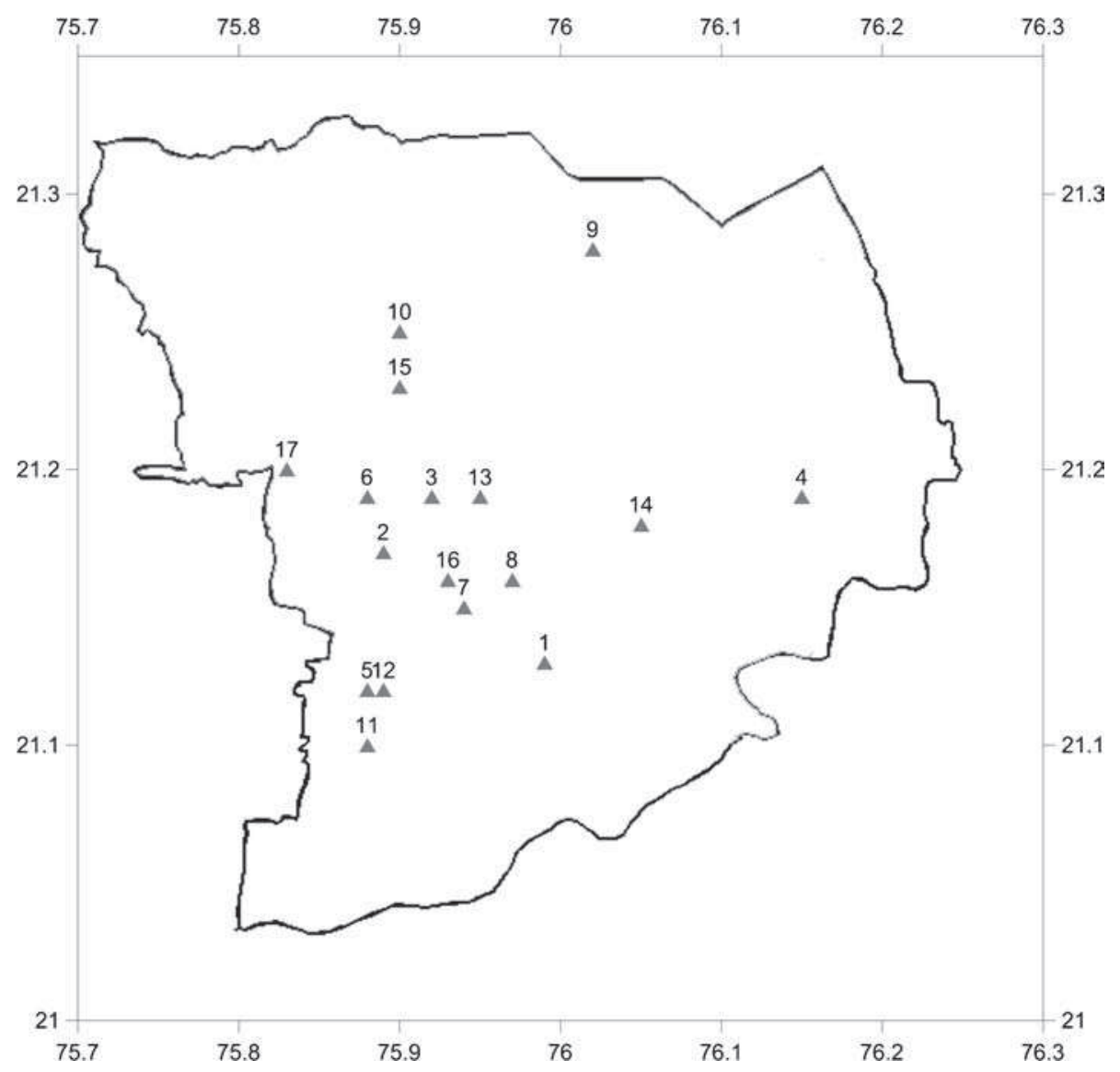

Figure 2. Location map of vertical electrical sounding points in the study area.

relates to $S$ (Ayolabi et al. 2010). It has also been reported that in an area where geoelectric environments are uniform, resistivity will not vary much and thus, $S$ will be proportional to $H$, which means that large $S$ values are indicative of deeper basement and vice versa (Murali and Patangay 2006). In the present study, very high $S$ values (9.64 and 9.3 ) are obtained at VES stations 12 and 2 and the corresponding depth to the bottom-most geoelectric layer is about 77 and $56 \mathrm{~m}$ having a resistivity of 172 and $96 \Omega-\mathrm{m}$, respectively, which might be the fractured basement in this area.

Clayey overburden, which is characterized by relatively high longitudinal conductance, offers protection to the underlying aquifer. According to the classification of Oladapo and Akintorinwa (2007), Atakpo (2013), the longitudinal unit conductance values facilitate to classify the area into poor, weak, moderate, good, very good and excellent protective capacity zones. Where the conductance is greater than 10, they are considered as zones of excellent protective capacity. The part having conductance values ranging from 5 to 10 was classified as zone of very good protective capacity; areas with $S$ values ranging from 0.7 to 4.9 were classified as exhibiting good protective capacity; the region where the conductance value is between 0.2 and 0.69 is considered as moderate protective capacity and the section having a conductance value in the range of 0.10.19 exhibits weak protective capacity, while the zones where the conductance value is less than 0.1 were considered to have poor protective capacity.

The $S$-map (figure 3a) revealed that about $18 \%$ of the area falls within the 'very good' protective capacity, while about $64 \%$ constitutes the 'good' protective capacity rating and the remaining $18 \%$ exhibits moderate/weak protective capacity. This suggests that the entire study area, which is characterized by relatively moderate to high longitudinal conductance, envisages good aquifer protective capacity rating. Clayey/silty overburden in this part, which is characterized by relatively high longitudinal conductance, offers protection to the underlying aquifers. Oteri (1981) reported that a marked increase in $S$ value may correspond to an average increase in the clay content and therefore, a decrease in the transmissivity of the aquifer. In the present study, one borehole lithology at VES 17 (figure 6) suggests that the $60 \mathrm{~m}$ litholog encountered clayey overburden with lenses of sand, pebbles, etc. The longitudinal conductance value at VES 17 is 2.4 and falls under good protective 


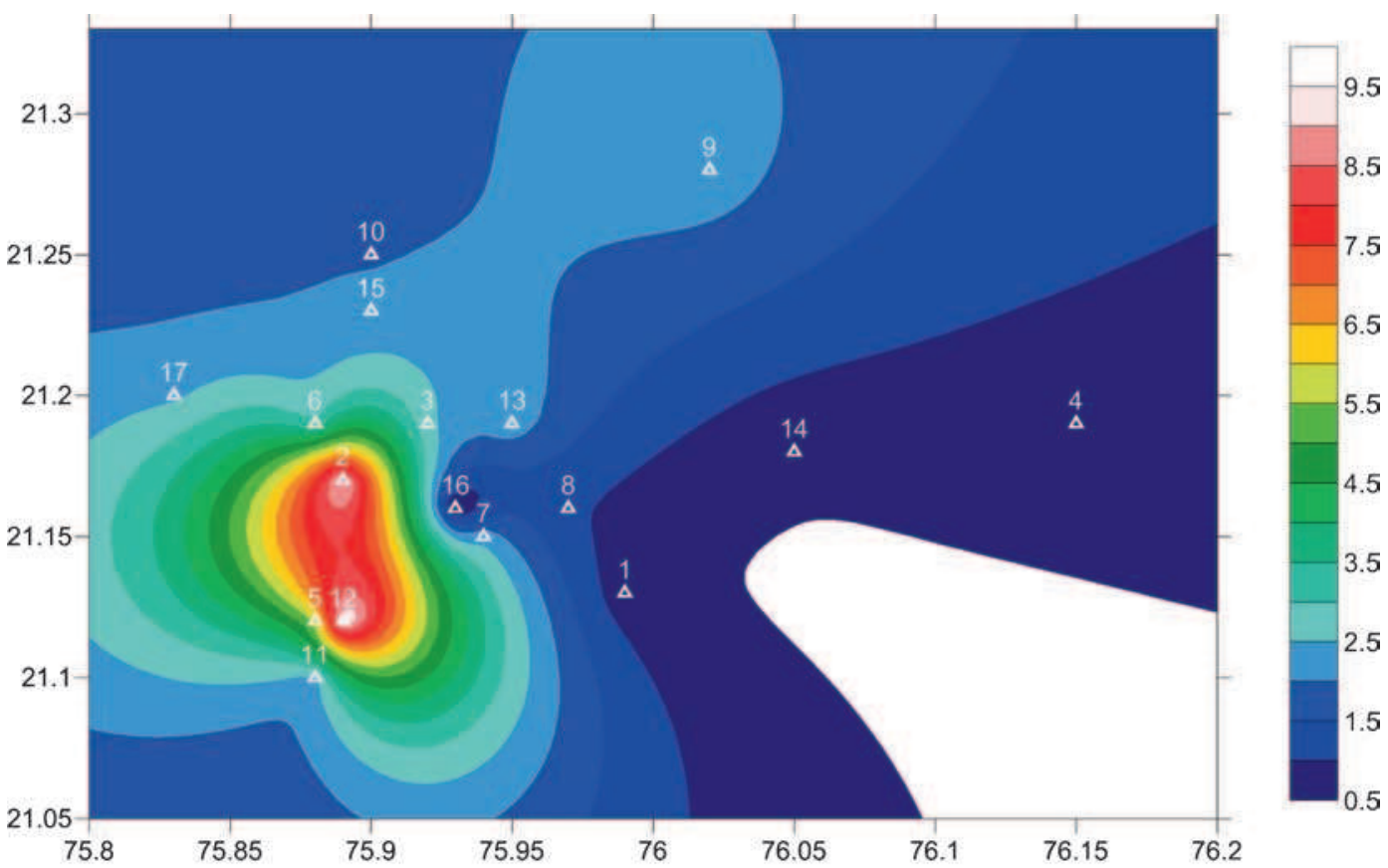

(a)

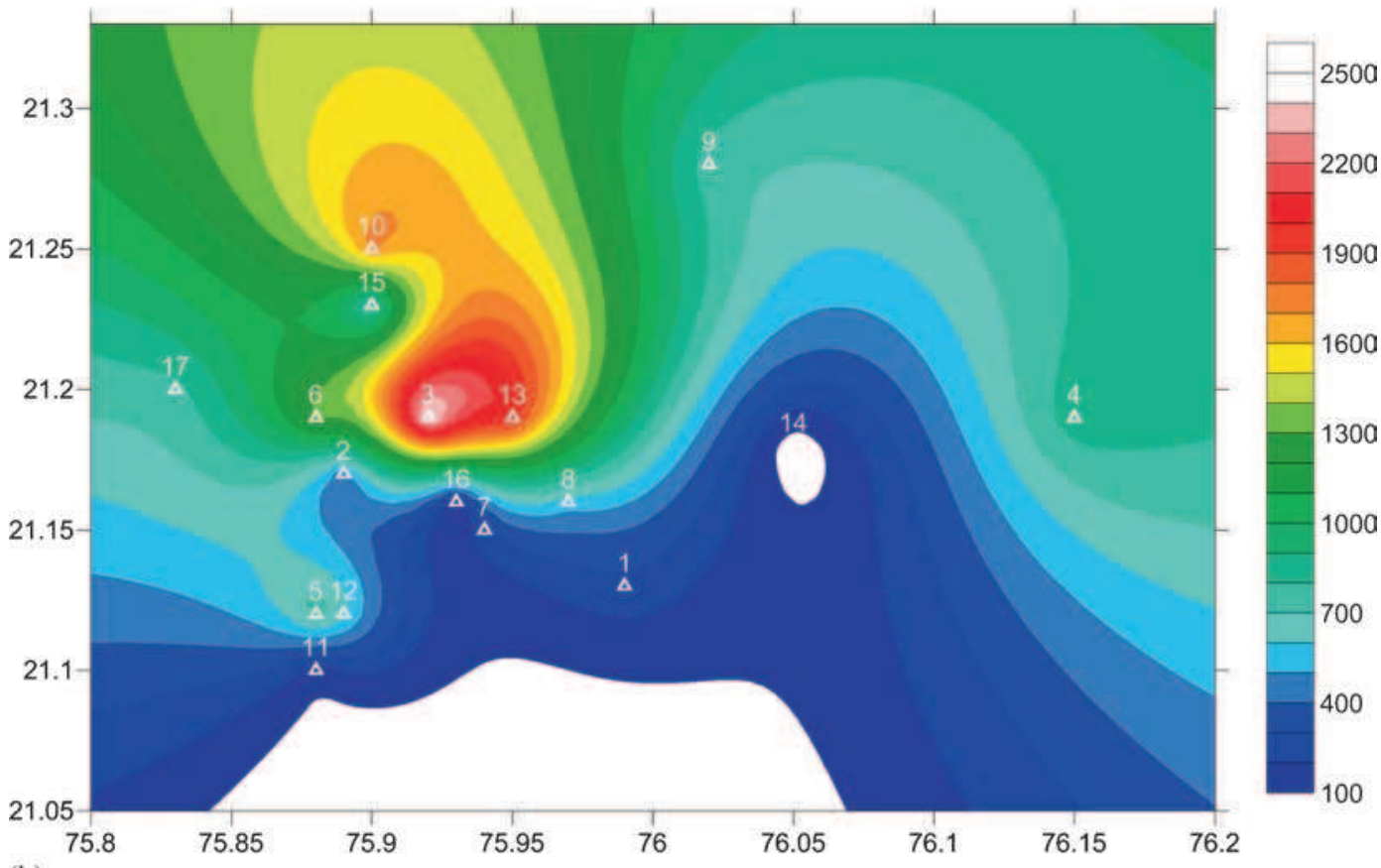

(b)

Figure 3. Spatial distribution of (a) longitudinal conductance $(S)$ in Seimens, $(\mathbf{b})$ transverse resistance $(T)$ in $\Omega$ - $\mathrm{m}^{2},(\mathbf{c})$ transverse resistivity $\left(\rho_{\mathrm{t}}\right)$ in $\Omega-\mathrm{m},(\mathbf{d})$ longitudinal resistivity $\left(\rho_{l}\right)$ in $\Omega-\mathrm{m}$, and (e) electrical anisotropy $(\lambda)$ in the study area.

capacity rating. Further from figure 3(a), it can be surmised that the central-western part of the study area reflects very good to good protective capacity rating as can be envisaged from the high longitudinal conductance values. The low value of the protective capacity is a consequence of the absence of significant amount of clay as an overburden impermeable material in the eastern part (VES stations 1, 4 and 14), thereby enhancing the percolation of contaminants into the aquifer. The aquifers here may be prone to contaminations such as industrial and agricultural wastes, septic tanks and landfills, if located close to the sounding points.

\subsubsection{Transverse unit resistance}

The transverse resistance $(T)$ contour map with a contour interval of $100 \Omega-\mathrm{m}^{2}$ is shown in 


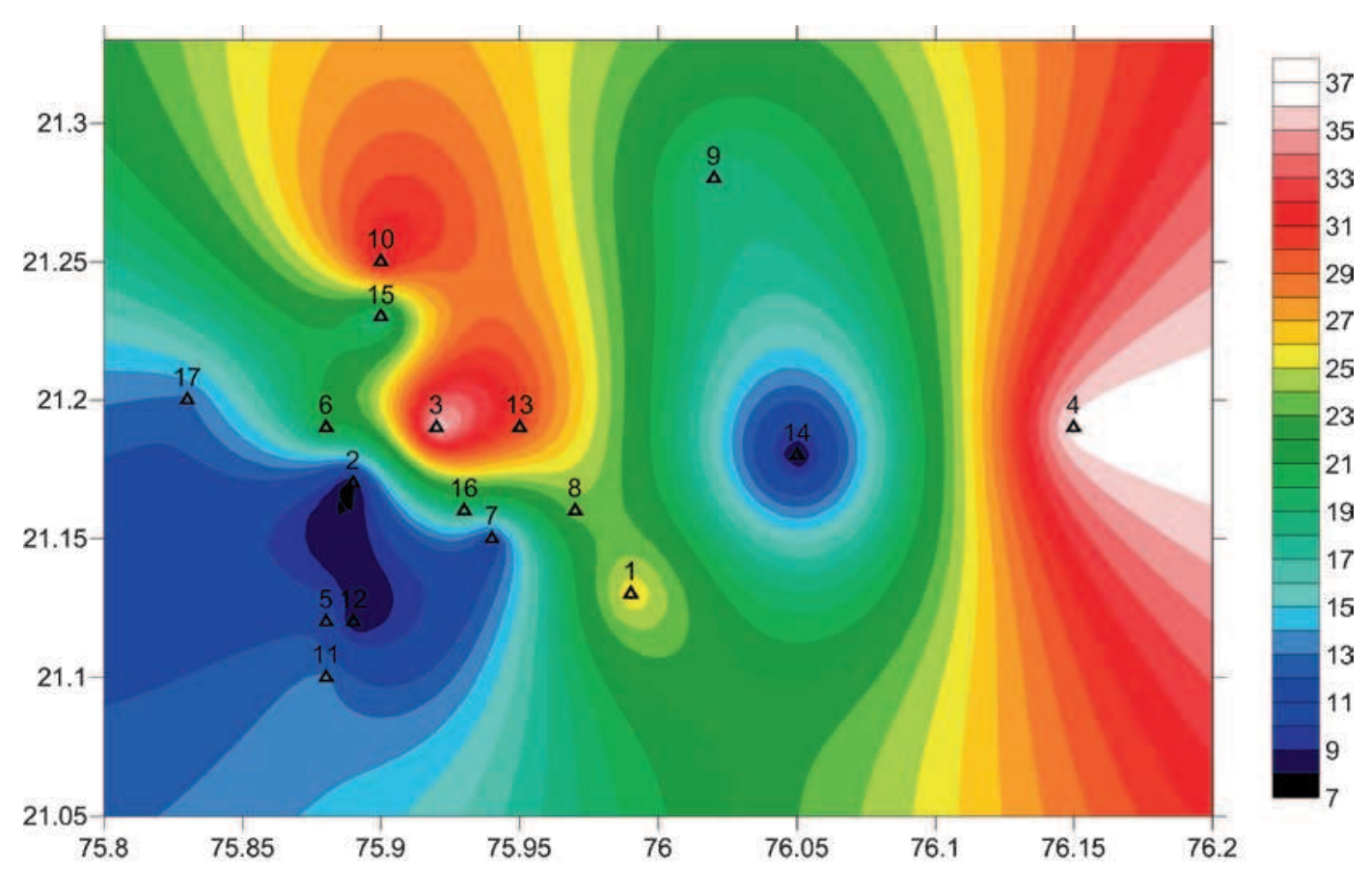

(c)

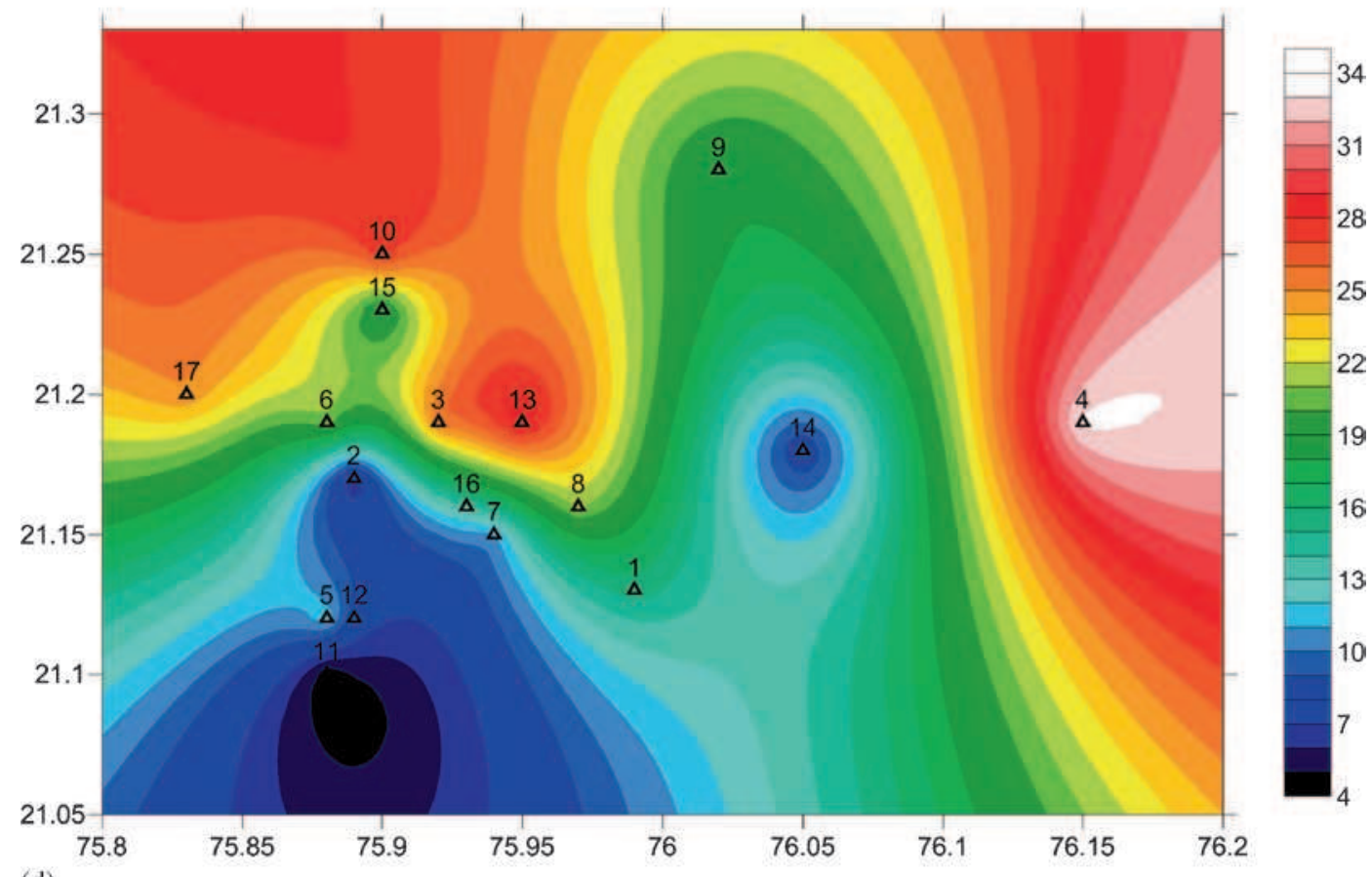

(d)

Figure 3. (Continued.)

figure 3(b). The $T$ value varies from a minimum of $36.5 \Omega-\mathrm{m}^{2}$ at VES 14 to a maximum of 2480 $\Omega-\mathrm{m}^{2}$ at VES 3. It is evident from figure 3(b) that high $T$ values $\left(>700 \Omega-\mathrm{m}^{2}\right)$ are encompassing VES stations $3,4,6,9,10,13,15$ and 17 in the study area, signaling fresh water zone. Increasing $T$ values indicate high transmissivity of aquifers. The south-eastern and southern part of the study area are characterized by low $T$ values $\left(<700 \Omega-\mathrm{m}^{2}\right)$.

\subsubsection{Transverse resistivity}

Figure 3(c) depicts the contour map for transverse resistivity $\left(\rho_{t}\right)$ with a contour interval of $1 \Omega-\mathrm{m}$. This map has a certain resemblance with the $T$ contour map (figure $3 \mathrm{~b}$ ). The northern part shows a broad feature with resistivities in excess of $25 \Omega-\mathrm{m}$ and is governed by the VES stations 3, 10 and 13 . The southern part encompassing VES points 2, 5, 


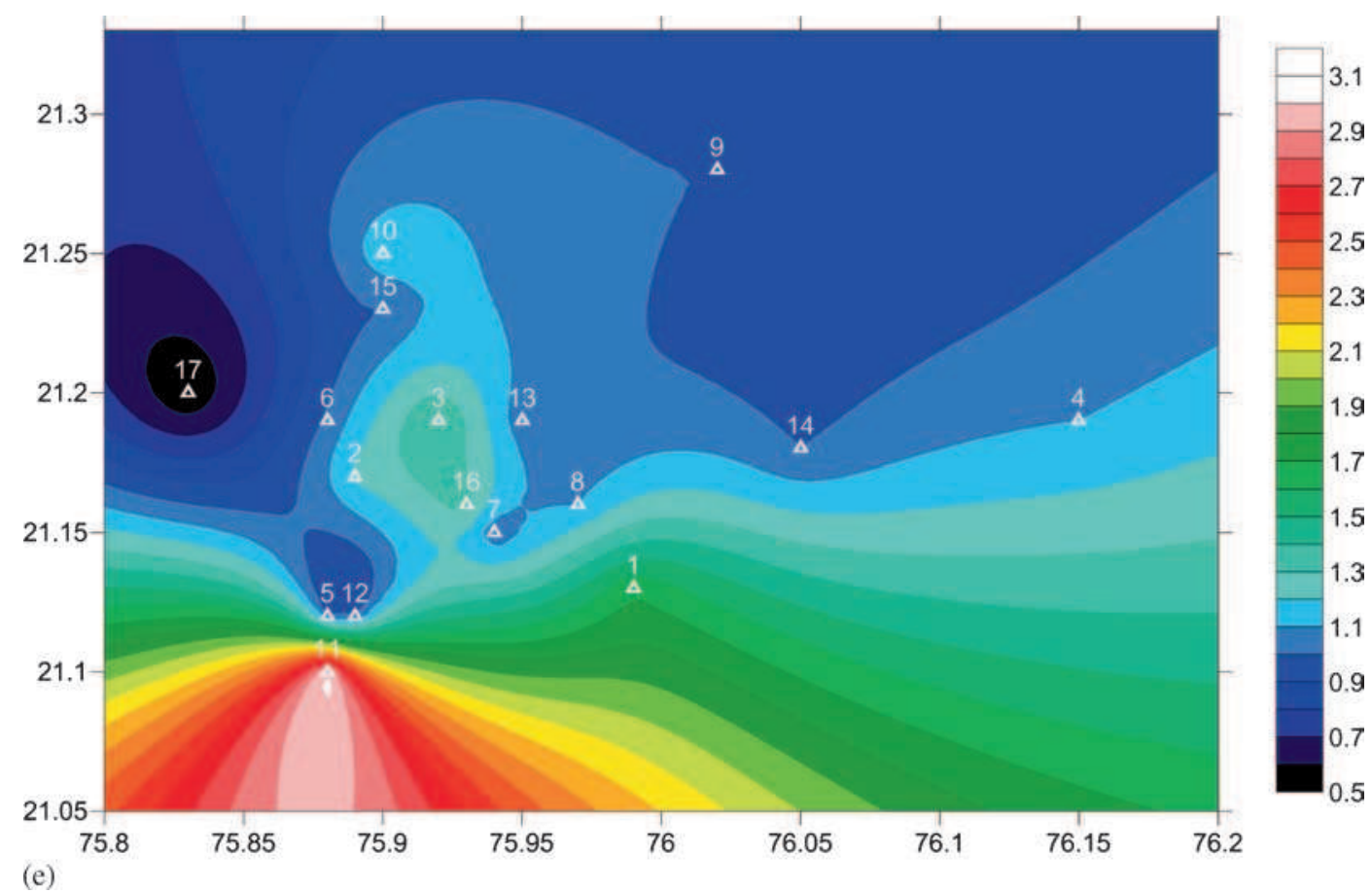

Figure 3. (Continued.)

7,11 and 12 is characterized by resistivities of the order of $7-15 \Omega-\mathrm{m}$. The central part of the study region is encompassed by resistivity values of about 16-24 $\Omega-\mathrm{m}$ indicating freshwater zone. The pockets of very low resistivity observed at VES 12 and 14 are probably due to contaminant waters caused by agricultural and domestic wastes. There is no effect of saline water intrusion in the transverse resistivity map.

\subsubsection{Longitudinal resistivity}

The contour map (contour interval of $1 \Omega-\mathrm{m}$ ) of longitudinal or horizontal component $\left(\rho_{l}\right)$ of resistivity values is shown in figure (3d). The entire study region shows the resistivity value of $4-33 \Omega-\mathrm{m}$. The northern part of the study region encompassing VES stations 3, 10 and 13 is characterized by resistivities in excess of $25 \Omega$-m. VES station 4 in the extreme eastern part of the study area indicates resistivity value in excess of $30 \Omega-\mathrm{m}$. Low resistivities in the range of $4-12 \Omega-\mathrm{m}$ is observed at VES stations $2,5,7,11-12$ in the southern part. The central and northwestern part of the map depicts moderate resistivity of the order of $13-22 \Omega-\mathrm{m}$.

The longitudinal resistivity $\left(\rho_{l}\right)$, in general, is less than the transverse resistivity $\left(\rho_{t}\right)$, unless the medium is uniform (Flathe 1955), which is observed in the present study also. This suggests that the current flow and average hydraulic conduction along the lithology boundary (longitudinal) are greater than those normal to the boundary plane (Ayolabi et al. 2010). Further, Keller (1982) opined that $\rho_{l}$ is dominated by the more conductive layers (in the present case, clay and weathered layers), whereas $\rho_{t}$ increases rapidly even if a small fraction of resistive layers are present.

\subsubsection{Electrical anisotropy}

The above-mentioned parameters introduce the concept of anisotropy $(\lambda)$, where the block of layers as one unit behaves like an anisotropic medium characterized by the longitudinal and transverse resistivities (Maillet 1947; Khalil 2009). The values of electrical anisotropy $(\lambda)$, as shown in table 2 , ranges from 0.5 (VES 17) to 3.0 (VES 11) with an average of 1.21 in the study area and its distribution is shown in figure 3(e). The coefficient of anisotropy is generally 1 and seldom exceeds 2 in most of the geological conditions (Zohdy et al. 1974). As the hardness and compaction of rocks increases, $\lambda$ also increases (Keller and Frischknecht 1966). These areas can thus be associated with low porosity and permeability. An area with $\lambda$ value $<1$ and up to 1.5 is considered to be a potential zone for groundwater (Singh and Singh 1970). As can be seen from figure 3(e), entire study area depicts a $\lambda$ value of around 1-1.5, except at VES point 11 . It can thus be suggested that the areas having lowest water table fluctuation is related with low $\lambda$ values and higher water table fluctuation regions are associated with high $\lambda$ values. Mondal et al. (2013) reported that the anisotropy in a hard rock area could be due to different geological layers in such a semi-arid region. 


\subsubsection{Root mean square resistivity}

The root mean square resistivity $\left(\rho_{m}\right)$, also known as effective resistivity, in the study region, as shown in table 2, ranges between 6.7 (VES station 2) and $34.96 \Omega-m$ (VES station 4). Khalil (2009) observed that when the longitudinal, transverse and mean resistivities differ, then the change in resistivity is dependent on the direction of groundwater flow and the influence of lithological variation. These three types of resistivity values are different in layered anisotropic sediments (Mazac et al. 1985; Ayolabi et al. 2010). In the present case, it is observed that the three resistivity values are different (except at VES 12) which reflect the fact that heterogeneous anisotropic lithology is encountered here.

\subsection{Geoelectrical modelling}

The 2-D geoelectrical section has been generated over four selected profiles in order to understand the geometry of the aquifer developed in and around the study area. The profiles are marked as Profile AB, Profile CD, Profile EF and Profile $\mathrm{GH}$ for the sake of discussion (figure 4). The $2-\mathrm{D}$ longitudinal geoelectrical model is shown in figures $5(\mathrm{a}-\mathrm{d})$.

\subsubsection{Profile $A B$}

The profile AB is trending $\mathrm{E}-\mathrm{W}$ and encompassing VES points $17,6,3,13,14$ and 4 . It can be seen from figure 5 (a) that the top $2 \mathrm{~m}$ is saturated with water below VES sites 17 and 6 on the western part. An aquifer zone is delineated up to depths of $10 \mathrm{~m}$ below VES 6 , having a resistivity of less than $16 \Omega-\mathrm{m}$. This low resistive zone extends further down and the direction of groundwater flow seems to be beneath VES 17 at depths of $40 \mathrm{~m}$. VES 17 and 6 are both potential zones for groundwater recharge. The dug well lithological cross-section at VES 17 is shown in figure 6. The litholog suggests that the aquifer zone lies at depths of about $47 \mathrm{~m}$. The VES study defines a resistivity value of about $12-16 \Omega-\mathrm{m}$ at depths of about $40 \mathrm{~m}$ and below for this zone. Thus, there is a clear correlation between resistivity data and litholog section at VES 17. As mentioned earlier, the longitudinal conductance $(S)$ at VES 17 is 2.4 and falls under good aquifer protective capacity rating.

VES 3 is characterized by a $30-\mathrm{m}$ thick high resistive $(>40 \Omega-\mathrm{m})$ oval-shaped body. This is due to weathered/fractured basalt. Further east of the profile below VES 13, 14 and 4, an expansive low resistive zone is encountered having resistivity of less than $15 \Omega-\mathrm{m}$. The thickness of this zone is thicker $(30 \mathrm{~m})$ beneath VES 14, while it thins down to about $3 \mathrm{~m}$ beneath VES 4 . Below this conductive zone, the entire stretch is moderately resistive (25-30 $\Omega-\mathrm{m})$ at depths below $30 \mathrm{~m}$ representing weathered/fractured basalt saturated with water.

\subsubsection{Profile $C D$}

Profile CD trending N-S comprises of VES stations 10, 15, 6, 2, 5, 12 and 11. The longitudinal cross-section (figure $5 \mathrm{~b}$ ) reveals that beneath VES 10 , the top layer is resistive $(>18 \Omega-\mathrm{m})$, indicating

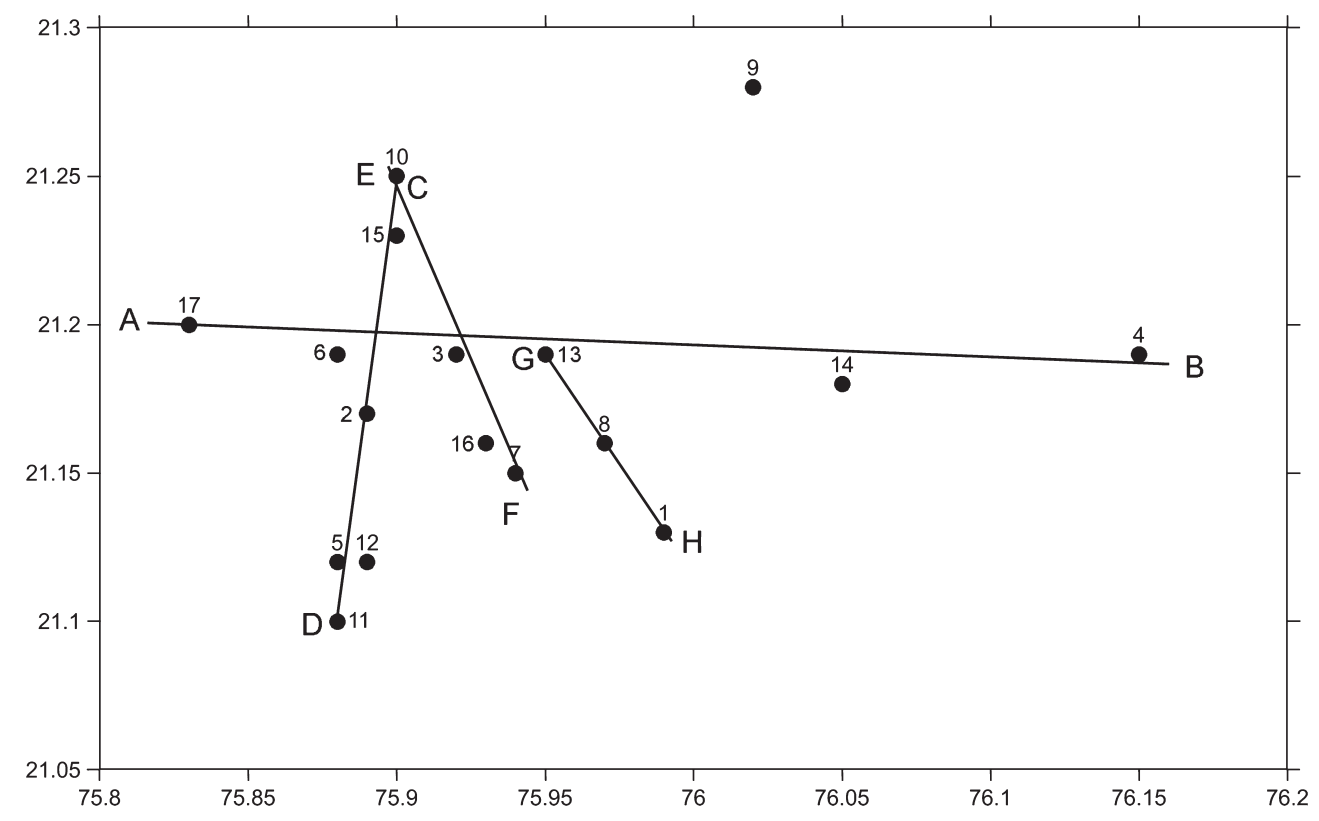

Figure 4. Location map of VES profiles (AB, CD, EF and GH). 

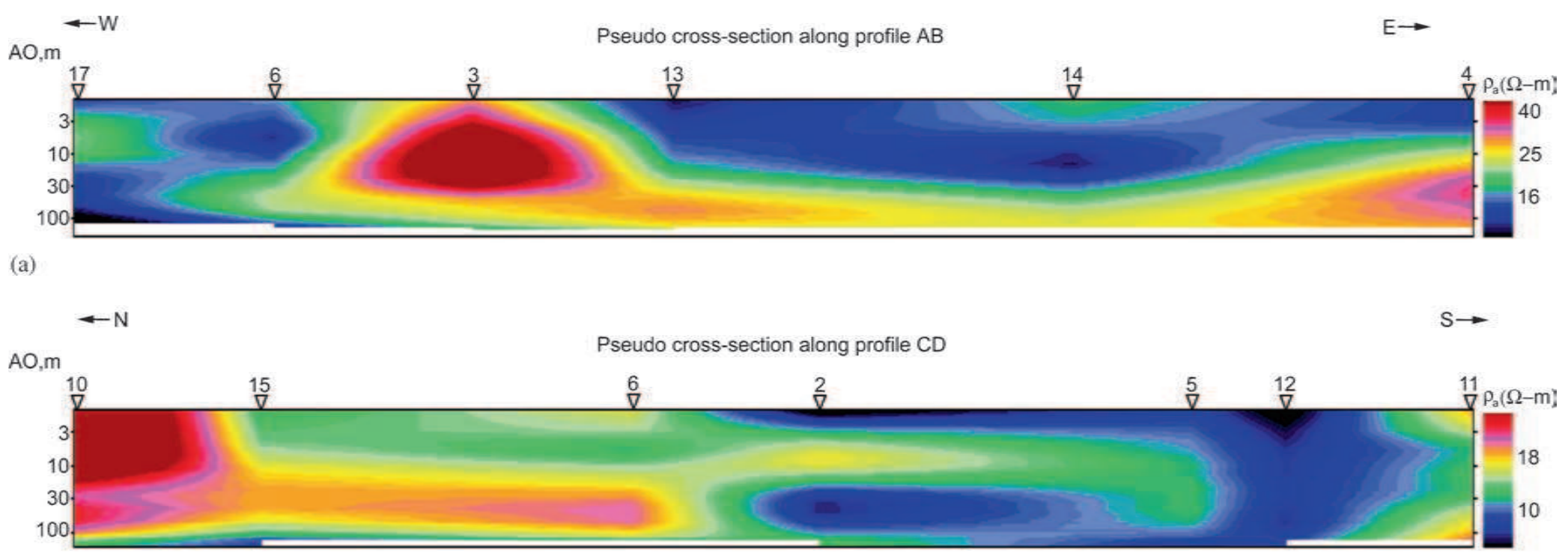

(b)

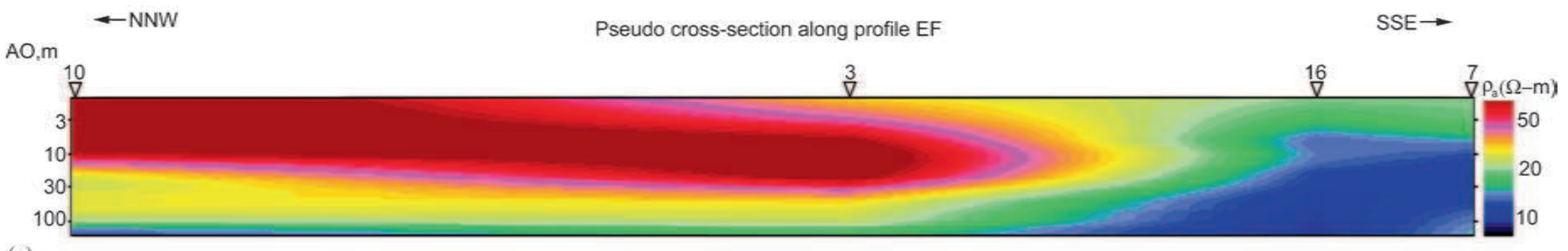

(c)

$$
\leftarrow \text { NW }
$$

Pseudo cross-section along profile $\mathrm{GH}$

$\mathrm{SE} \rightarrow$

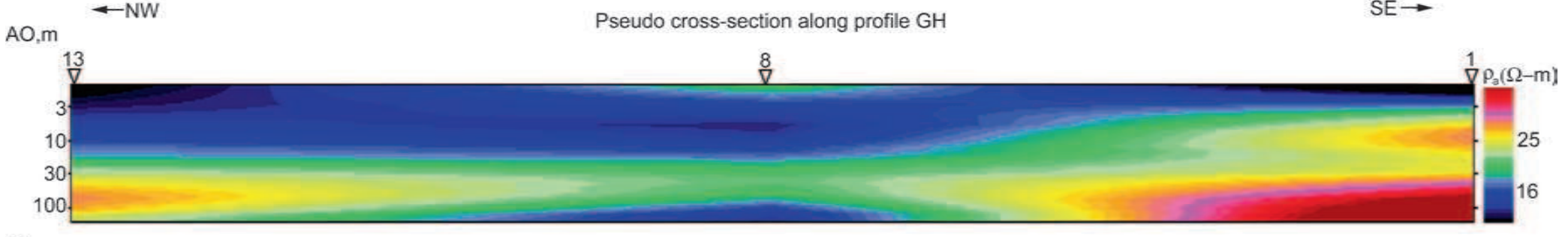

(d) 


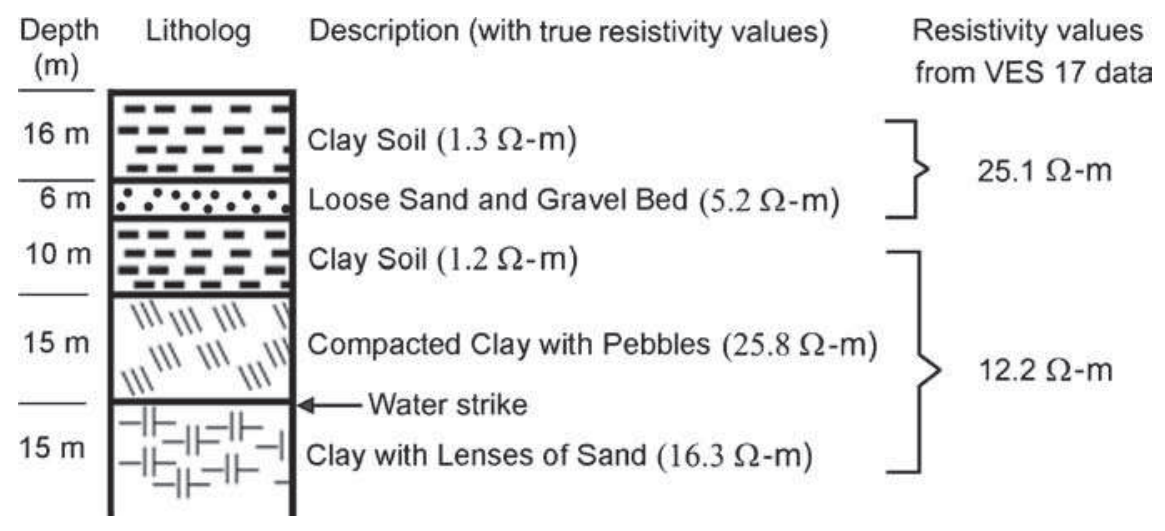

Figure 6. Correlation of one-dimensional inversion of Schlumberger vertical electrical sounding of station 17 along with the dug well lithology of the study area.

hard and compact rock at the top and seems to continue up to depth of penetration. The top 3-5 $\mathrm{m}$ below VES 15 and 6 is conductive (about $15 \Omega-\mathrm{m})$ underneath which a resistive $(>18 \Omega-\mathrm{m})$ layer is delineated. The top layer in longitudinal geoelectric section beneath VES 2 and 5 depicts a thin conductive $(<10 \Omega-\mathrm{m})$ layer, below which a moderately resistive (about $15 \Omega$-m) layer is observed. Below this, a conductive layer at depths of $30 \mathrm{~m}$ is revealed having resistivities in the range of $5-10 \Omega-\mathrm{m}$. Further south, a wide low resistive $(5-10 \Omega-\mathrm{m})$ feature is demarcated beneath VES 12. This low resistive feature extends from shallow depths up to depths of investigation. This is a potential aquifer zone and the groundwater flow is both in south (below VES 11) and north (beneath VES 5 and 2) directions. VES sites 2, 5 and 12 and potential aquifer zones are over this profile.

\subsubsection{Profile EF}

This profile, as presented in figure $5(\mathrm{c})$, consists of VES stations 10, 3, 16 and 7 from NNW-SSE. Below VES stations 10 and 3 towards north, a 20 -m thick high resistive $(>50 \Omega-\mathrm{m})$ layer is encountered, which is representative of hard and compact rock. Below this, moderate resistive ( $25 \Omega-\mathrm{m})$ layer is observed which is inferred as clay with lenses of sand. Further south, the top $10 \mathrm{~m}$ below VES stations 16 and 7 is conductive (about $20 \Omega-\mathrm{m}$ ), beneath which a very conductive $(5-10 \Omega-\mathrm{m})$ zone is encountered up to depths of investigation. Both VES 16 and 7 are conducive for groundwater exploration.

\subsubsection{Profile $G H$}

This profile, as shown in figure $5(\mathrm{~d})$, is trending NW-SE and comprises of VES stations 13, 8 and 1. The top layer over the entire stretch of the profile is highly conductive $(<10 \Omega$-m) suggesting clayey layer saturated with water. This layer is $10 \mathrm{~m}$ thick beneath VES 13 and 8 and thins down to about $3 \mathrm{~m}$ beneath VES 1. Beneath this layer a moderately resistive $(>25 \Omega-\mathrm{m})$ zone is delineated throughout the profile.

\section{Discussion}

From the above-mentioned analysis and results, it is seen that the Dar-Zarrouk (D-Z) parameters are highly useful to comprehend the spatial distribution of groundwater in addition to the geometry of the sub-surface litho units and provide an indication to aquifer prospective zones in the study area. The advantage of using D-Z parameters to estimate protective capacity is that the non-uniqueness of interpreting resistivity data is minimized. These parameters provide a positive solution as they reflect very clear, conspicuous and widely varying ranges of sub-surface resistivities. They also do not possess an overlapping character and in turn facilitate easy resolution. These results also give a useful first approximation of the $\mathrm{D}-\mathrm{Z}$ parameter variation and could be used to site exploratory boreholes.

The aquiferous zones are clearly reflected in the longitudinal conductance $(S)$ and transverse resistance $(T)$ maps. The longitudinal conductance values reveal about $18 \%$ of the area, falls within the 'very good' protective capacity, about $64 \%$ constitutes the 'good' protective capacity rating, while $18 \%$ exhibits moderate to weak protective capacity suggesting that the entire study area, which is characterized by relatively moderate-to-high longitudinal conductance, envisages good aquifer protective capacity rating. Clayey/silty overburden in this part, which is characterized by relatively high longitudinal conductance, offers protection to the underlying aquifers. 
As mentioned earlier, the entire area is exhibiting moderate-to-high $S$ values (0.39-9.64), thus indicating that clayey overburden is dominant in this region. Due to an increase in clay content, a decrease in transmissivity of aquifer is expected. However, the protective capacity rating of the aquifer is good at most of the sites. The low values of protective capacities at some stations in the eastern part of the study area indicate that the overburden material has no clayey overlying strata, which is a risk to groundwater contamination. Figure 6 shows the correlation between a borehole $\log$ at VES 17, which consists of five different types of geological formations together with their depths and true resistivity values. However, the disagreement in the number of layers obtained from the borehole log and VES 17 data is due to the large contrast in the resistivity between bedrock and regolith which often masks the presence of suppressed layers of intermediate resistivity, representing fractured bedrock that often contains significant quantities of water, encountered in drilling (Maiti et al. 2013b).

High $T$ values (above $700 \Omega-\mathrm{m}^{2}$ ) are evident at VES stations 3, 4, 6, 9, 10, 13, 15 and 17, mostly in the central part of the study area indicating freshwater regime. High $T$ values are related with zones of high transmissivity and thus are highly porous to water movement. Such zones suggest that the groundwater aquifers have a high tendency of being contaminated, a fact which can be envisaged from VES 4, which has very low $S$ and high $T$ values. The low protective capacities of the overburden material and the high aquifer transmissivities will help the leaching of contaminants and migration within the aquifer system. Deolankar (1980) reported that the weathered basalt shows highest aggregate porosity (34\%) in Deccan Volcanic Province (DVP), whereas the specific yield is less (around 7\%). Though the porosity is high, the specific yield is very small signifying higher specific retention of the weathered basalt. This may be caused due to the presence of clay minerals in the weathered basalt which has higher water retention capacity.

It is also seen from the longitudinal geoelectric sections that the central-western part of the study area has high potential of fresh water aquifers at average depths of about $40 \mathrm{~m}$. Potential aquifer zones are VES sites 17, 6, 13, 14 and 4 over Profile AB. The dug well lithological cross-section along with the true resistivities of different formations at VES 17 is shown in figure 6 . The aquifer zone in the dug well lies at depths of about $47 \mathrm{~m}$, whereas the VES 17 data defines a resistivity value of about $12-16 \Omega-\mathrm{m}$ at depths of about $40 \mathrm{~m}$ and below for this zone. Thus, there is a clear corroboration between resistivity data and litholog section at VES 17. Over profile CD, potential aquifer zones are revealed at VES sites 2, 5 and 12. VES sites 16 and 7 over Profile EF are ideal aquifer zones. However, a few VES points further south of VES 7 would have given the complete picture of the low resistivity zone. VES point 8 over Profile GH is a potential aquifer zone.

\section{Conclusion}

Geophysical mapping of Suki river basin in Raver sub-division of Jalgaon district, Maharashtra was carried out using Wenner electrical soundings. The interpreted result of the 17 VES points reveal aquifers are made of clay, weathered and fractured rocks. Combination of sounding results, borehole lithology and geoelectric (Dar-Zarrouk) parameters signify potential aquifer zones at VES stations $2,5,6,7,12,13,14$ and 17 . The centralsouthern part of the study area has high groundwater potential due to the backwaters of Hatnur dam.

The overburden protective capacity in the area was evaluated using the longitudinal unit conductance values. This is due to the fact that the earth medium acts as a natural filter to percolating fluid and that its ability to retard and filter percolating fluid is a measure of its protective capacity. High clay content which impeded fluid movement is generally characterized by low resistivity values and low hydraulic conductivities and thus, low longitudinal unit conductance, enabling classification of the study area into weak, moderate and good protective capacity zones. The longitudinal conductance map suggests good aquifer protective capacity rating in most parts of the study area. The D-Z parameters also reveal heterogeneous anisotropic lithology in the study area.

It is seen that the estimation of $\mathrm{D}-\mathrm{Z}$ parameters for evaluation of aquifer protection studies is of considerable significance in terms of societal issues like groundwater exploration and protection from pollution. Further, this result will be useful to gain a better understanding of the complex geology of the area and should provide basis for future detailed water resource study using electrical resistivity tomography (ERT) and very low frequency (VLF) techniques.

Due to the change from normal cropping pattern to cash crops, especially those which require more water, there is over-exploitation of water resources in Raver sub-division. Though the surface water resources are available in the area and all the surface/groundwater resources are rain-dependent, a need to cultivate the habit of resource conservation has become a must for the community of 
this area. Thus, change in cropping pattern with low water requirement crops should be encouraged. The disused dug wells along Hatnur dam can be recharged by canal water in monsoon season, mostly in central and southern parts of the area.

\section{Acknowledgements}

The authors are grateful to Dr D S Ramesh, Director, IIG for the keen interest and encouragement during the course of the work and allowing to publish the same. The authors are obliged to Prof. S T Ingle, North Maharashtra University, Jalgaon, for many fruitful suggestions.

\section{References}

Adeoti L, Alile O M and Uchegbulam O 2010 Geophysical investigation of saline water intrusion into freshwater aquifers: A case study of Oniru, Lagos State; Scientific Research and Essays 5(3) 248-259.

Atakpo E A 2013 Aquifer vulnerability investigation using geoelectric method in parts of Sapele Local Government area of Delta State, Nigeria; Nigerian J. Basic Appl. Sci. 21(1) 11-19.

Atakpo E A and Ayolabi E A 2008 Evaluation of aquifer vulnerability and the protective capacity in some oil producing communities of western Niger Delta; Environmentalist $29310-317$.

Ayolabi E A 2005 Geoelectric evaluation of Olushosun landfill site southwest Nigeria and its implication on groundwater; J. Geol. Soc. India 66 318-322.

Ayolabi E A, Folorunso A F and Oloruntola M O 2010 Constraining causes of structural failure using electrical resistivty tomography (ERT): A case study of Lagos, southwestern Nigeria; Mineral Wealth 156 7-18.

Bobachev A 2003 Resistivity sounding interpretation. IPI2WIN: Version 3.0.1, a 7.01.03; Moscow State University.

Bose R N and Ramakrishna T S 1978 Electrical resistivity surveys for ground water in the Deccan trap country of Sangli district, Maharashtra; J. Hydrol. 38 209-221.

CGWB website, http://cgwb.gov.in/CR/achi_geo_stu.html.

Chavan M B and Nile K S 2012 Comparative study of quantitative and cartographic techniques of Banana crop concentration in Raver Tehsil of Jalgaon District (M.S., India); J. Geog. Geol. 4(2) 108-114, doi: 10.5539/jgg.v4n2p108.

Dahlin T 2000 Electrode charge-up effects in DC resistivity data acquisition using multi-electrode arrays; Geophys. Prospect 48(1) 181-187.

Deolankar S B 1980 The Deccan basalt of Maharashtra, India - Their potential as aquifers; Groundwater 18(5) 434-437.

Deshpande G G 1998 Geology of Maharashtra; Geological Society of India, Bangalore, 223p.

Devi S P, Srinivasulu S and Raju K K 2001 Delineation of groundwater potential zones and electrical resistivity studies for groundwater exploration; Environ. Geol. 40 1252-1264.

Edet A E and Okereke C S 2001 A regional study of saltwater intrusion in southeastern Nigeria based on the analysis of geoelectrical and hydrochemical data; Environ. Geol. 40 1278-1289.
El-Qady G, Ushijima K and El-Sayed A 2000 Delineation of a geothermal reservoir by $2 \mathrm{D}$ inversion of resistivity data at Hammam Faraun area, Sinai, Egypt; Proceeding World Geothermal Congress, pp. 1103-1108.

Flathe H 1955 Possibilities and limitations in applying geoelectrical methods to hydrogeological problems in the coastal area of northwest Germany; Geophys. Prospect. 3 95-110.

Frohlich R K, Barosh P J and Boving T 2008 Investigating changes of electrical characteristics of the saturated zone affected by hazardous organic waste; J. Appl. Geophys. $6425-36$.

Ghosh P, Sayeed M R G, Islam R and Hundekari S M 2006 Inter-basaltic clay (bole-bed) horizons from Deccan traps of India: Implications for palaeo-climate during Deccan trap volcanism; Palaeogeogr. Palaeoclimatol. Palaeoecol. 242 90-109.

Gupta G, Erram V C and Kumar S 2012 Temporal geoelectric behaviour of dyke aquifers in northern Deccan Volcanic Province, India; J. Earth System Sci. 121(3) 723-732.

Gupta G, Maiti S and Erram V C 2014 Analysis of electrical resistivity data in resolving the saline and fresh water aquifers in west coast Maharashtra, India; J. Geol. Soc. India $84555-568$.

Hamzah U, Samudin A R and Malim E P 2007 Groundwater investigation in Kuala Selangor using vertical electric sounding (VES) surveys; Environ. Geol. 51 1349-1359.

Henriet J P 1976 Direct application of Dar-Zarrouk parameters in ground water surveys; Geophys. Prospect. 24 344-353.

Hermans T, Daoudi M, Vandenbohede A, Robert T, Caterina D and Nguyen F 2012 Comparison of temperature estimates from heat transport model and electric resistivity tomography during a shallow heat injection and storage experiment; Berichte Geol. B.-A. 93 Applications in Geothermal Monitoring.

Hodlur G K, Dhakate R and Andrade R 2006 Correlation of vertical electrical sounding and borehole-log data for delineation of saltwater and freshwater aquifers; Geophysics 71(1) G11-G20.

Karlik G and Kaya M A 2001 Investigation of groundwater contamination using electric and electromagnetic methods at an open waste-disposal site: A case study from Isparta, Turkey; Environ. Geol. 40 725-731.

Keller G V 1982 Electrical properties of rocks and minerals; In: Handbook of physical properties of rocks (ed.) Carmichael R S, CRC Press, pp. 217-293.

Keller G V and Frischknecht F C 1966 Electrical methods in geophysical prospecting; Pergamon, Oxford, 526p.

Khalil M H 2006 Geoelectric resistivity sounding for delineating salt water intrusion in the Abu Zenima area, west Sinai, Egypt; J. Geophys. Eng. 3 243-251.

Khalil M H 2009 Hydrogeophysical assessment of Wadi El-Sheikh aquifer, Saint Katherine, South Sinai, Egypt; J. Environ. Eng. Geophys. 14(2) 77-86.

Kumar D, Thiagarajan S and Rai S N 2011 Deciphering geothermal resources in Deccan trap region using electrical resistivity tomography technique; J. Geol. Soc. India 78 541-548.

Kundu M C and Mandal B 2009 Assessment of potential hazards of fluoride contamination in drinking groundwater of an intensively cultivated district in West Bengal, India; Environ. Monit. Assess. 152 97-103.

Lamsoge B R 2009 Groundwater information, Jalgaon district, Maharashtra; CGWB Technical Report No. 1606/DBR/2009, 23p.

Lenkey L, Hamori Z and Mihalffy P 2005 Investigating the hydrogeology of a water supply area using direct-current 
vertical electrical soundings; Geophysics 70(4) H11H19.

Maillet R 1947 The fundamental equation of electrical prospecting; Geophysics 12 529-556.

Maiti S, Gupta G, Erram V C and Tiwari R K 2011 Inversion of Schlumberger resistivity sounding data from the critically dynamic Koyna Region using hybrid Monte Carlo-based neural network approach; Nonlin. Process. Geophys. 18 179-192.

Maiti S, Erram V C, Gupta G, Tiwari R K, Kulkarni U D and Sangpal R R 2013a Assessment of groundwater quality: A fusion of geochemical and geophysical information via Bayesian neural networks; Environ. Monit. Assess. 185 3445-3465, doi: 10.1007/s10661-012-2802-y.

Maiti S, Gupta G, Erram V C and Tiwari R K 2013b Delineation of shallow resistivity structure around Malvan, Konkan region, Maharashtra by neural network inversion of vertical electrical sounding measurements; Environ. Earth Sci. 68 779-794, doi: 10.1007/s12665-012-1779-8.

Majumdar R K, Majumdar N and Mukherjee A L 2000 Geoelectric investigations in Bakreswar geothermal area, West Bengal, India; J. Appl. Geophys. 45 187-202.

Mazac O, Kelley W E and Landa I 1985 A hydrogeological model for relations between electrical and hydraulic properties of aquifer; J. Hydrol. 79 1-19.

Mondal N C, Singh V P and Ahmed S 2013 Delineating shallow saline groundwater zones from southern India using geophysical indicators; Environ. Monit. Assess. 185 4869-4886.

Murali S and Patangay N S 2006 Principles of application of groundwater geophysics; Association of Geophysicists, Hyderabad India, 3rd edn, 371p.

Niwas S and Singhal D C 1981 Estimation of aquifer transmissivity from Dar-Zarrouk parameters in porous media; J. Hydrol. 50 393-399.

Niwas S and Singhal D C 1985 Aquifer tranmissivity of porous media from resistivity data; J. Hydrol. 82 143-153.

Oladapo M I and Akintorinwa O J 2007 Hydrogeophysical study of Ogbese southwestern Nigeria; Global J. Pure Appl. Sci. 13(1) 55-61.

Oladapo M I, Mohammed M Z, Adeoye O O and Adetola B A 2004 Geoelectrical investigation of the Ondo State Housing Corporation Estate, Ijapo Akure, southwestern Nigeria; J. Mining Geol. 40(1) 41-48.

Oteri A U 1981 Geoelectric investigation of saline contamination of chalk aquifer by mine drainage water at Tilmanstone, England; Geoexploration 19 179-192.

Park Y H, Doh S J and Yun S T 2007 Geoelectric resistivity sounding of riverside alluvial aquifer in an agricultural area at Buyeo, Geum River watershed, Korea: An application to groundwater contamination study; Environ. Geol. 53 849-859.

Pawar N J, Pawar J B, Supekar A, Karmalkar N R, Kumar S and Erram V C 2009 Deccan dykes as discrete and prospective aquifers in parts of Narmada-Tapi zone, Dhule District, Maharashtra; In: Indian Dykes (GSI Special Volume) (eds) Rajesh K Srivastava, Ch Sivaji and Chalapathi Rao N V, Narosa Publishing House Pvt. Ltd., New Delhi, India, pp. 189-198.

Rai S N, Thiagarajan S and Ratnakumari Y 2011 Exploration of groundwater in the basaltic Deccan traps terrain in Katol taluk, Nagpur district, India; Curr. Sci. 101(9) 1198-1205.

Rai S N, Thiagarajan S, Ratna Kumari Y, Anand Rao V and Manglik A 2013 Delineation of aquifers in basaltic hard rock terrain using vertical electrical soundings data; J. Earth Syst. Sci. 122(1) 29-41.

Ratnakumari Y, Rai S N, Thiagarajan S and Dewashish Kumar 2012 2D electrical resistivity imaging for delineation of deeper aquifers in a part of the Chandrabhaga river basin, Nagpur District, Maharashtra, India; Curr. Sci. 102(1) 61-69.

Salem H S 1999 Determination of fluid transmissivity and electric transverse resistance for shallow aquifers and deep reservoirs from surface and well-log measurements; Hydrol. Earth Syst. Sci. 3(3) 421-427.

Shahid S and Nath S K 2002 Estimation of aquifer parameters from surface geoelectric measurements for the selection of suitable well sites; J. Appl. Hydrol. 15(1) 41-49.

Singh C L and Singh S N 1970 Some geoelectrical investigations for potential groundwater in part of Azamgrah area of UP; Pure Appl. Geophys. 82 270-285.

Singh U K, Das R K and Hodlur G K 2004 Significance of Dar-Zarrouk parameters in the exploration of quality affected coastal aquifer systems; Environ. Geol. $\mathbf{4 5}$ 696-702.

Singhal B B S 1997 Hydrogeological characteristics of Deccan trap formations of India; In: Hard Rock Hydrosystems; IAHS Publ. No. 241 75-80.

Song S H, Lee J Y and Park N 2007 Use of vertical electrical soundings to delineate seawater intrusion in a coastal area of Byunsan, Korea; Environ. Geol. 52 $1207-1219$.

Zohdy A A R, Eaton G P and Mabey D R 1974 Application of surface geophysics to ground-water investigation; Techniques of water-resources investigation series of the United States Geological Survey, 2nd edn. 